\title{
ANALISIS PERANAN SISTEM INFORMASI AKUNTANSI DALAM E-COMMERCES TERHADAP PENGENDALIAN BISNIS ONLINE
}

\section{ANALYSIS OF THE ROLE OF ACCOUNTING INFORMATION SYSTEMS IN E-COMMERCES ON ONLINE BUSINESS CONTROL}

\author{
Tumpal Manik \\ Fakultas Ekonomi Universitas Maritim Raja Ali Haji (Tanjungpinang) \\ Email : tmanyk@gmail.com dan tmanik@umrah.ac.id
}

\begin{abstract}
ABSTRAK
Tujuan penelitian ini dilakukan untuk meneliti analisis penerapan sistem informasi akuntansi dan audit electronic data processing melalui electronic commerce dalam mengendalikan transaksi pembayaran on-line. Penelitian ini mengunakan jenis penelitian deskriptif kualitatif. Hasil ppenelitian memberikan arahan dalam pengendalian bisnis online, yaitu bahwa Peranan Sistem informasi akuntansi terhadap pengendalian bisnis Online terdiri dari tiga kelompok pengendalaian, antara lain: a) Pengendalian Audit Electronic Data Processing (Audit EDP); (b) Pengendalian Sistem Online; (c) Pengendalian Aplikasi; pengendalian memberikan keyakinan yang wajar bahwa kegiatan bisnis dilaksanakan secara tepat dan. Kedua Peranan Sistem informasi akuntansi dalam Electronic Commerce terhadap Pengendalian Bisnis On-Line, bahwa Pengendalain bisnis online menggunakan jaringan online internet untuk transaksi sebagai salah satu aspek terpenting dalam sistem infomasi akuntansi untuk mengendalikan akses atau modifikasidata secara ilegal, phishing, zombies, denial of service, gangguan virus, worm, trojan pada sistem operasi komputer atau data, pencurian data, pemalsuan web atau situs pembeli.
\end{abstract}

Kata Kunci : Sistem Informasi Akuntansi, E-commerce, Bisnis online

\begin{abstract}
The purpose of this study was to examine the analysis of the application of accounting information systems and electronic data processing audits through electronic commerce in controlling online payment transactions. This study uses a type of qualitative descriptive research. The results of the study provide direction in controlling online business, namely that the role of the accounting information system for controlling online business consists of three control groups, including: a) Electronic Data Processing Audit (EDP Audit); (b) Online System Control; (c) Application Control; control provides reasonable assurance that business activities are carried out appropriately and. Second Role of accounting information systems in Electronic Commerce on Online Business Control, that online business control uses internet online networks for transactions as one of the most important aspects in accounting information systems to control access or modify illegally, phishing, zombies, denial of service, interference with viruses, worms, trojans on computer or data operating systems, data theft, web falsification or buyer sites.
\end{abstract}

Keywords : Accounting Information Systems, E-commerce, Online Business 


\section{PENDAHULUAN}

Kemajuan dan perkembangan teknologi informasi saat ini berdampak pada kemajuan teknologi jaringan, menyebabkan terjadinya perubahan kultur bisnis. Dalam era yang disebut "information age" ini, media elektronik menjadi salah satu media andalan untuk melakukan komunikasi dan bisnis. Kemajuan era informasi mengharuskan perusahaan untuk mengubah mind-set mereka. Perusahaan harus melakukan investasi besar dalam bidang teknologi informasi dan konektivitas jaringan, investasi mereka dalam teknologi informasi terkadang jauh melebihi investasi untuk pabrik dan peralatan. Pemanfaatan internet pada masa era globalisasi ini telah semakin meningkat penggunaannya oleh berbagai kalangan, baik individu maupun kelompok, termasuk kalangan organisasi khususnya para pengusaha.

Penemuan software untuk aplikasi bisnis merupakan dampak positif dari kemajuan teknologi informasi saat ini dengan mengadopsi teknologi informasi seperti melalui jaringan internet. Salah satu contohnya penggunaan layanan fasilitas dari electronic commerces (ecommerces) yang mempunyai fitur dan kontens yang sangat lengkap untuk layanan pembelian dan pembayaran, karena memiliki keunggulan-keunggulan dalam membantu segala aktivitas bisnis organisasi (perusahan). Fasilitas layanan dari aplikasi e-commerce dimanfaatkan untuk membantu transaksi perusahaan seperti transaksi jual-beli mulai dari proses pemesanan, pembuatan order, pengiriman invoice, billing sampai penerimaan pembayaran dan proses pencatatan akuntansi kemudian menghasilkan laporan keuangan.

E-Commercess merupakan interaksi antara eksternal dengan internal perusahan seperti interkasi dengan para pemasok, pelanggan, investor, kreditor, pemerintah dan media komunikasi yang mampu melakukan transmisi pertukaran informasi yang dimediasi secara elektronik didalam perusahan dangan pihak luar.

Pemanfaatan fasilitas internet melalui konfogurasi jaringan world wide webs (www) sebagai dasar pengembangan perdagangan electronic commerce, hal ini sering menimbulkan permasalahan yang cukup pelik dalam manajemen perusahaan selama proses bisnis berjalan khususnya pengendalian pembayaran secara on-line, maka diperlukan pengendalian melalui sistem informasi akuntansi (SIA) dan audit electronic data processing (EDP). Pengendalian melalui sistem informasi akuntansi dan audit electronic data processing, mencakup jejak audit (audit trail), pengendalian umum (general controls), pengendalian aplikasi (application controls), penilaian resiko pengendalian dan pengujian pengendalian (tests of controls).

Permasalahan dari fasilitas pembayaran melalui layanan internet dalam e-commerce, tidak bisa lagi dilihat hanya dari disiplin penegakan hukum, pengendalian teknis dan etika bertransaksi online, namun perlu ditinjau ulang dari peranan sistem informasi akuntansi dan audit electrinik data processing yang terhubung dengan online internet. Berdasarkan permasalahan yang diuraikan diatas, maka penulis tertatik untuk meneliti tentang analisis penerapan sistem informasi akuntansi dan audit electronic data processing melalui electronic commerce dalam mengendalikan transaksi pembayaran on-line.

Berdasarkan pendahulan diatas, maka rumusan masalah dalam penelitian ini adalah apakah bagaimanakah penerapan sistem informasi akuntansi dan audit electronic commerce terhadap pengendalian bisnis online. Sedangkan tujuan penelitian ini adalah untuk menganalisis penerapan sistem informasi akuntansi dan audit electronic commerce dalam pengendalian bisnis online 


\section{LANDASAN TEORI}

\section{Sistem Informasi Akuntansi (SIA)}

Aplikasi komputer akuntansi merupakan penggabungan dari sistem akuntansi, akuntansi, sistem informasi manajemen dan teknologi informasi menjadi satu paket dan meghasilkan software untuk memproses transaksi dalam perusahaan, yang mampu mengolah data transaksi yang telah diimput oleh user dengan metode dan pencatatan yang dibuat oleh manajemen untuk mengidentifikasi, menghimpun, menganalisis, mengelompokkan, mencatat dan melaporkan informasi ekonomi.

Sistem informasi akuntansi merupakan suatu kerangka dari entitas-entitas pengkordinasian sumber daya yang terdiri dari data, meterials, equipment, suppliers, personal, and funds untuk mengkonversi input berupa data ekonomik menjadi keluaran berupa informasi keuangan yang digunakan untuk melaksanakan kegiatan suatu entitas dan menyediakan informasi akuntansi bagi pihak-pihak yang berkepentingan. Sedangkan menurut Bodnar (2006), menyatakan sistem informasi akuntansi merupakan kumpulan sumberdaya, peralatan yang dirancang untuk mengubah data keuangan dan data lainnya kedalam informasi.

Keputusan dari hasil pemrosesan teknologi komputer ke dalam sistem informasi akuntansi keuangan, telah mengubah cara kerja para pegawai pada posisi keuangan dan akuntansi, yaitu dalam penyimpanan data, pengambilan kembali data, dan pengendalian hanya melalui komputer. Data yang tersimpan dalam komputer akan memudahkan proses audit teknologi informasi (Audit EDP), dimana proses audit electronic data processing terdapat tiga cara digunakan dalam melaksanakan prosedur audit dengan menggunakan komputer antara lain : pemroses data pengujian auditor pada sistem komputer klien sebagai bagian dari pengujian pengendalian, menguji pembukuan yang diselenggarakan komputer sebagai sarana untuk melakukan verifikasi atas laporan keuangan klien, menggunakan komputer untuk melaksanakan tugas audit yang terpisah dari catatan klien.

Menurut Bodnar (2007), sistem informasi akuntansi adalah sistem yang mengumpulkan dan memproses data transaksi serta menyajikan informasi keuangan kepada pihak-pihak yang berkepentingan. Sistem informasi berkembang sepanjang waktu dan menjadi semakin kompleks seiring dengan perkembangan organisasi. Sedangkan menurut Romney (2007), sistem informasi akuntansi terdiri dari lima komponen antara lain (a) orang-orang yang mngoperasikan sistemtersebut dalam melaksanakan berbagai fungsi, (b) prosedur-prosedur, baik manual maupun yang terorganisasi yang melibatkandalam pengumpulan, memproses, dan menyimpan data, (c) data tentang prosedur-prosedur bisnis organisasi, (d) software yangdipakai untuk memproses data organisasi, (e) infrastruktur teknologi informasi, termasuk komputer, peralatan pendukung dan peralatan komunikasi jaringan.

Menurut penelitian Noviari (2008), yang meneliti Pengaruh Kemajuan Teknologi Informasi Terhadap Perkembangan Akuntansi, menemukan bahawa kemajuan teknologi mempengaruhi perkembangan akuntansi. Peranan TI terhadap perkembangan akuntansi pada setiap babak berbeda-beda. Semakin maju TI, semakin banyak pengaruhnya pada bidang akuntansi. Hal-hal yang perlu diperhatikan dalam aplikasi sistem informasi akuntansi adalah bagaimana dasar merancang sistem dalam perusahaan yang berhubungan dengan harta perusahaan untuk menjaga aset-aset perusahaan, mengumpulkan data dan mengkaitkannya dengan aktivitas organisasi dalam komputerisasi akuntansi, juga menyalurkan data dan informasi. 


\section{Electronic Commerces (E- Commerces)}

Pemanfaatan teknologi e-commerces dan website saat ini telah berkembang, hal ini disebabkan infrastruktur yang ada saaat ini sudah memadai, seiring dengan penggunaan teknologi internet yang semakin luas, indikator untuk teknologi informasi dan komunikasi (ICT) dalam beberapa tahun terakhir di Indonesia cukup meningkat secara signifikan dan membawa dampak transformational pada berbagai aspek kehidupan, termasuk di dalamnya dunia bisnis.

Teknologi e-business dan website di Indonesia untuk sekarang ini telah berkembang. Hal ini disebabkan infrastruktur yang ada saaat ini sudah memadai, ketersediaan pekerja yang ahli tentang teknologi informasi (IT), keterlibatan lembaga keuangan/perbankan kurang akibat peningkatan pengetahuan dan tingkat pendidikan pengguna (user). Walaupun demikian, seiring dengan penggunaan teknologi internet yang semakin luas, indikator untuk teknologi informasi dan komunikasi (ICT) dalam beberapa tahun terakhir di Indonesia cukup meningkat secara signifikan (Tumpal Manik, 2016)

Pengendalian electronic commerce merupakan pengendalian ini didesain untuk memberikan keyakinan bahwa hasil perhitungan telah diprogram dengan benar, logika yang digunakan dalam proses pengolahan adalah benar, file yang digunakan dalam proses pengolahan adalah benar, record yang digunakan dalam proses pengolahan adalah benar, operator telah memasukkan data ke komputer sebagaimana mestinya, selama proses pengolahan adalah benar, selama proses pengolahan telah digunakan standar operasi yang semestinya, data yang tidak sah jangan digunakan dalam proses pengolahandata.

E-commerce atau bisa disebut perdagangan elektronik atau e-dagang adalah penyebaran, pembelian, penjualan, pemasaran barang dan jasa melalui sistem elektronik seperti internet atau televisi, www, atau jaringan komputer lainnya. Menurut Westberg dalam Depkeu Indonesia (2007), e-commerce mengacu kepada tranaksi pembelian dan penjualan atau transaksi bisnis yang dilakukan melalui media komputer dan telekomunikasi, artinya penggunaan jaringan komputer untuk betransaksi terkait proses produksi, penjualan dan pendistribusian barang atau jasa.

Transaksi melalui e-commerce dapat melibatkan transfer dana elektronik, pertukaran data elektronik, sistem manajemen inventori otomatis, dan sistem pengumpulan data otomatis (Nurharyanto,2009). Industri teknologi informasi melihat kegiatan e-dagang ini sebagai aplikasi dan penerapan dari e-bisnis (e-business) yang berkaitan dengan transaksi komersial, seperti: transfer dana secara elektronik, SCM (supply chain management), e-pemasaran (e-marketing), atau pemasaran online (online marketing), pemrosesan transaksi online (online transaction processing), pertukaran data elektronik (electronic data interchange-EDI).

Menurut O'Brien dan Marakas (2010), mendefinisikan e-Commerce: "is changing the shape of competition, the speed of action, and the streamlining of interaction, and payment from customer to companies, and from companies to suppliers." Sedangkan menurut Seminar (2008), e-Commerce adalah membeli atau menjual informasi, produk dan jasa melalui jaringan computer yang menggunakan internet, intranet ataupun extranet. Lebih lanjut dijelaskan bahwa eCommerce memiliki empat prespektif. Pertama adalah komunikasi, yaitu untuk memberikan informasi produk atau jasa dan pembayaran. Menurut Marcella Elwina S (2011), Perkembangan teknologi informasi sehubungan dengan transformasi global yang melanda dunia membawa akibat pada berkembangnya aktivitas perdagangan, salah satunya adalah perdagangan atau transaksi melalui media elektronik (transaksi e-commerce). 


\section{Sistem Informasi Akuntansi dalam E-Commerces}

Kegiatan e-commerce ini merupakan aplikasi dan penerapan dari e-bisnis (e-business) yang berhubungan dengan transaksi komersial, misalnya: transfer dana secara elektronik, SCM (supply chain management), pertukaran data elektronik (electronic data interchange /EDI), pemasaran online (online marketing), atau e-pemasaran (e-marketing), pemrosesan transaksi online (online transaction processing). Jaringan internet digunakan untuk mengirim informasi keseluruh pengguna internet di berbagai belahan dunia selama duapulu empat jam, karena melibatkan clien-server yaitu progran sistem robot yang menjalankan beberapa komputer secara konstanta dan mengelola informasi yang dibutuhkan oleh pengguna apliksi e-commerce.

Sistem informasi akuntansi dalam e-commerces melalui pemanfaatan teknologi e-business sekarang ini telah berkembang. Hal ini disebabkan infrastruktur yang ada saaat ini sudah memadai, ketersediaan pekerja yang ahli tentang teknologi informasi (IT), keterlibatan lembaga keuangan/perbankan kurang akibat peningkatan pengetahuan dan tingkat pendidikan pengguna (user), kini saatnya SIA mengadopsi TI di era elektronik yang ditandai dengan menjamurnya kegiatan usaha antara lain adalah e-business, e-commerces, e-economy, e-university, egovernment, e-entertainment, e-service, dan masih banyak lagi istilah sejenis.

Jenis server di internet di jelaskan oleh Bodnar (2007), seperti mail server, file server, web server, dan server perdagangan. (a) Mail server merupakan kotak pos elektronik yang berfingsi menyimpan surat elektronik yang datang sampai program klien meminta surat tersebut. (b) File server adalah berperan memberikan izin kepada klien yang sah untuk mengambil file dari pustaka file yang berada pada suatu komputer. (c) Web server adalah suatu server yang memungkinkan penggunaa (klien) mengakses dokumen secara fisik berada di komputer lain. (d) Web server merupakan engine yang menjalankan word wide web (www). Protokol yang menentukan format dokumen di word wide web yang disebut dengan hypertex markup language (HTML) yaitu mengkonversikan dokumen ke dalam format yang mudah dibaca oleh penggunan. menggunakan kombinsai perangkat keras yang disebut firewall untuk membatasi akses dari pihak luar.

Menurut Tumpal Manik( 2016), bahwa e-commerce merupakan salah satu unit media b iksnis yang terintegrasi dengan teknologi informasi berupa aplikasi perdagangan dan bisnis yang menghubungkan perusahaan atau perseorangan sebagai konsumen untuk melakukan transaksi elektronik, pertukaran barang atau produk dan jasa, dan pertukaran informasi melalui jaringan internet yang menggunakan internet, intranet ataupun extranet. E-commerce memiliki empat prespektif. Pertama adalah komunikasi, yaitu untuk memberikan informasi produk atau jasa dan pembayaran. Kedua adalah bisnis, yaitu membuat otomatisasi transaksi bisnis dan workflows. Ketiga pelayanan, yaitu berhubungan dengan pengurangan biaya guna peningkatan kualitas dan percepatan service delivery. Terakhir adalah online, yaitu memiliki kemampuan menyediakan pembelian dan penjualan produk menggunakan internet atau pelayanan online yang lainnya

E-Commerce lebih dari membeli dan menjual secara online, tetapi termasuk juga proses pengembangan, pemasaran, pelayanan dan pembayaran produk atau jasa; yang ditransaksikan pada internetworked global marketplaces dengan bantuan worldwide network. Sehingga dapat disimpulkan bahwa e-Commerce adalah suatu kegiatan pemasaran secara luas yang meliputi proses pembelian, penjualan, pelayanan dan pengembangan lainnya dengan memanfaatkan media internet sebagai alat komunikasi efektif antara penjual dengan pembeli sehingga diharapkan aksesnya dapat dilakukan dengan mudah serta real time-based. 
Kegiatan e-commerce ini merupakan aplikasi dan penerapan dari e-bisnis (e-business) yang berhubungan dengan transaksi komersial, misalnya: transfer dana secara elektronik, SCM (supply chain management), pertukaran data elektronik (electronic data interchange /EDI), pemasaran online (online marketing), atau e-pemasaran (e-marketing), pemrosesan transaksi online (online transaction processing), sehingga E-Commerce dapat didefinisikan dari berbagai macam persepsi, antara lain (1) Komunikasi; pengiriman barang, jasa, informasi, atau pembayaran melalui jaringan computer, (2) Perdagangan atau Niaga. Menyediakan kemampuan pembelian dan penjualan produk, jasa, dan informasi pada internet dan layanan online lainnya, (3) Proses Bisnis adalah melakukan bisnis secara elektronis dengan menyelesaikan dan melengkapi proses bisnisnya secara jaringan elektronik, oleh karenanya menggantikan informasi untuk proses bisnis secara fisik. (4) Layanan/Jasa adalah alat yang menunjukkan keinginan pemerintah, perusahaan, konsumen, dan manajemen untuk memotong biaya jasa sambil meningkatkan kualitas layanan dan kecepatan jasa layanan kepada pelanggan. (5) Pembelajaran yaitu yang memungkinkan pelatihan dan pendidikan secara online di sekolah, universitas dan organisasi yang lain, termasuk bisnis. (6) Komunitas adalah menggabungkan tempat untuk anggota komunitas untuk belajar, transaksi, dan kolaborasi.

Jenis-Jenis Transaksi E-Commerce dibedakan menurut pihak-pihak yang melakukan transaksi.

a) Busines to Busines (B2B), Busines to Busines (B2B) juga dapat diartikan sebagai system komunikasi bisnis online antar pelaku bisnis. Bentuk dadi B2B dapat berupa transaksi InterOrganizational System (IOS), misalnya transaksi extranet dan electronic funds transfer.

b) Bussines To Cunsumer (B2C); merupakan transaksi ritel dengan pembeli individual. Selain itu B2C juga dapat berarti mekanisme toko online (electronic shoping mall) yaitu transaksi antara e-merchant dengan e-customer. Business to Consumer E-Commerce memiliki permasalahan yang berbeda.

c) Consumer to Consumer $(\mathrm{C} 2 \mathrm{C})$; transaksi dimana konsumen menjual produk secara langsung kepada konsumen lainnya. Dapat diartikan pula saat seorang individu yang mengiklankan produk barang atau jasa, pengetahuan, maupun keahliannya di web.

d) Consumer To Bussines (C2B); merupakan individu yang menjual produk atau jasa kepada organisasi dan individu yang mencari penjual dan melakukan transaksi. Dalam Consumerto-Business konsumen memberitahukan kebutuhan atas suatu produk atau jasa tertentu, dan para pemasok bersaing untuk menyediakan produk atau jasa tersebut kekonsumen.

Model Bisnis dalam e-Commerce yang dapat dilakukan oleh perusahaan untuk menghasilkan uang pada lingkungan bisnisnya menggunakan web antara lain; (a) Brokerage Model : Broker adalah pencipta pasar, (b) Advertising Model; Model periklanan web merupakan perpanjangan dari model siaran media tradisional. (c) Infomediary Model; data mengenai konsumen dan kebiasaan konsumsi mereka sangat berharga, terutama ketika informasi secara berhati-hati dianalisis dan digunakan untuk kampanye pemasaran. (d) Merchant Model : Grosir dan penjual eceran barang dan jasa. (e) Manufacturer (Direct) Model; Para produsen "model langsung", didasarkan pada kekuatan web yang memungkinkan produsen (yaitu, sebuah perusahaan yang menciptakan produk atau jasa) untuk mencapai pembeli secara langsung. (f) Affiliate Model ; berusaha mendorong volume tinggi lalu lintas ke satu situs, model afiliasi, membuka peluang untuk pembelian di mana pun orang mungkin berada. (g) Community Model : Viabilitas model masyarakat didasarkan atas loyalitas pengguna. 


\section{Sistem Informasi Akuntansi dalam Business On Line}

Menurut pendapat Budilaksono (2011), Audit EDP adalah suatu proses mengumpulkan data dan menilai bukti untuk menentukan apakah sistem komputer mampu mengamankan aset, memelihara kebenaran data, mampu mencapai tujuan organisasi perusahaan secara efektif dan menggunakan aset perusahaan secara hemat. Penerapan teknologi informasi untuk mendukung operasional sebuah organisasi atau organisasi, memberi dampak yang sangat besar terhadap kinerja organisasi. Semakin besar ketergantungan suatu organisasi, semakin besar pula kerugian yang akan dihadapi organisasi tersebut, bila terjadi kegagalan sistem informasinya. Bentuk kegagalan fungsi sistem informasi ini dapat beraneka ragam, mulai dari kegagalan sistem kelistrikan, serangan hacker, virus, pencurian data, bencana alam, sampai dengan adanya serangan teroris.

Pengendalian business online merupakan bagian dari kegiatan audit electronic, yankni pengendalian aplikasi dan penendalian sistem informasi.Menurut Singleton (2007), membagi kegiatan audit yang utama menjadi lima antara lain : (a) audit internal, (b) audit teknologi informasi,(c) audit penipuan, (d) audit eksternal (yaitu audit keuangan), (5) auditor internal. Teknik dan metode yang digunakan melaksanakan Audit EDP, (James Hall,2007) ada tiga yakni: pertama adalah pertama, auditing sekitar komputer (audit around the computer) dapat dilakukan jika dokumen sumber tersedia dalam bahasa non-mesin memungkinkan auditor menelusuri suatu transaksi dari dokumen sumber ke output. Kedua adalah audit melalui komputer (audit through the computer), Auditor menguji dan menilai efektivitas prosedur pengendalian operasi dan program komputer serta ketepatan proses di dalam komputer. Keunggulan teknik ini adalah bahwa auditor memiliki kemampuan yang besar dan efektif dalam melakukan pengujian terhadap sistim komputer. Ketiga adalah audit dilakukan dengan menggunakan komputer (audit with the computer) dan software untuk mengotomatiskan prosedur pelaksanaan audit.

Penerapan siklus pengendalian aplikasi dalam organisasi akan membantu untuk pengembangan sistem serta pemeliharaan sistem komputerisasi yang terhubung dengan internet. Menurut James Hall (2009), penerapan siklus pengendalian sistem akan memberikan keyakinan yang wajar apabila siklus tersebut dilaksanakan secara tepat, yaitu (a) pengendalian sistem aplikasi, (b) pengendalian terhadap operasi komputer, (c) pengendalian pada sistem software, (d) pengendalian terhadap program dan input data, (e) pengendalian proses, (f) pengendalian aplikasi mencakup pengendalian atas masukan pengendalian atas pengolahan dan file data komputer, pengendalian atas keluaran, dan pengendalian masukan, pengolahan dan keluaran dalam sistem on line.

Terknologi informasi melalui jaringan, mampu merubah desain bisnis seperti e-business dan e-commerce. Penggunaan e-business ini menimbulkan berbagai keuntungan karena perusahaan dapat melakukan berbagai kegiatan bisnis secara elektronik tanpa batas dan kendala waktu. Kegiatan bisnis itu meliputi transaksi bisnis, operasi fungsi-fungsi perusahaan, sharing informasi khususnya dengan pelanggan dan suplier sehingga hubungan antara pihakpihak tersebut dnegan perusahaan dapat terjalin baik sebelum, selama dan setelah proses pembelian. Aktifitas bisnis secara elektronik ini (e-business/e-commerce) telah memberikan beberapa kemudahan baik bagi penjual maupun bagi pembeli.

Pemanfaatan teknologi e-business dan website di Indonesia untuk sekarang ini telah berkembang. Hal ini disebabkan infrastruktur yang ada saaat ini sudah memadai, ketersediaan pekerja yang ahli tentang teknologi informasi (IT), keterlibatan lembaga keuangan/perbankan 
kurang akibat peningkatan pengetahuan dan tingkat pendidikan pengguna (user). Walaupun demikian, seiring dengan penggunaan teknologi internet yang semakin luas, indikator untuk teknologi informasi dan komunikasi (ICT) dalam beberapa tahun terakhir di Indonesia cukup meningkat secara signifikan.

Sistem informasi akuntansi mengadopsi teknologi informasi sesuai dengan perkembangan teknologi informasi yang sangat dramatis dalam beberapa tahun terakhir telah membawa dampak transformational pada berbagai aspek kehidupan, termasuk di dalamnya dunia bisnis. Beberapa bisnis dan kegiatan online yang terintegrasi akuntansi dalam teknologi informasi setelah berlalunya era total quality dan reengineering, kini saatnya SIA mengadopsi TI di era elektronik yang ditandai dengan menjamurnya kegiatan usaha antara lain adalah e-business, ecommerces, e-economy, e-university, e-government, e-entertainment, e-service, dan masih banyak lagi istilah sejenis. Salah satu konsep yang dinilai merupakan paradigma bisnis baru adalah e-business atau dikenal pula dengan istilah e-commerce sebagai bidang kajian yang relatif masih baru dan akan terus berkembang, e-business berdampak besar pada praktek bisnis, setidaknya dalam hal penyempurnaan direct marketing, transformasi organisasi, dan redefinisi organisasi.

\section{METODE PENELITIAN}

Metode penelitian pada dasarnya merupakan cara ilmiah untuk mendapatkan data dengan tujuan dan kegunaan tertentu (Sugiono, 2011). Cara ilmiah berarti kegiatan penelitian itu didasarkan pada ciri-ciri keilmuan yang rasional, empiris, dan sistematis. Rasional berarti kegiatan penelitian itu dilaksanakan dengan cara-cara yang masuk akal sehingga terjangkau oleh penalaran manusia. Empiris berarti cara-cara yang dilakukan itu dapat diamati oleh indera manusia, sedangkan sistematis artinya proses penelitian itu menggunakan langkah-langkah tertentu yang bersifat logis dan ilmiah diharapkan data yang diperoleh adalah merupakan data yang objektif, valid, dan realible.

\section{Jenis penelitian}

Jenis penelitian ini adalah penelitian deskriptif kualitatif, sedangkan metode penyusunan penelitian ini, penulis mengumpulkan data-data serta keterangan-keterangan yang diperoleh dengan menggunakan :

1. Metode Pendekatan yaitu metode pendekatan yang digunakan penulis dalam penelitian ini adalah metode pendekatan secara yuridis empiris, yaitu suatu pendekatan yang dilakukan untuk menganalisa tentang sejauh manakah sistem informasi akuntansi dan audit EDP dalam e-commerce untuk mengendalikan transaki pembayaran melalui online internet.

2. Spesifikasi Penelitian yaitu spesifikasi penelitian yang digunakan dalam penyusunan penelitian ini adalah penelitian yang bersifat deskriftif analitis. Bersifat deskriptif, bahwa hasil dari penelitian ini diharapkan dapat diperoleh gambaran secara menyeluruh dan sistematis mengenai sistem informasi akuntansi dan audit EDP dalam e-commerce dan transaki pembayaran melalui online internet. 


\section{HASIL DAN PEMBAHASAN}

\section{Sistem Informasi Akuntansi Dalam Mengendalikan Bisnis On-Line}

Sistem informasi akuntansi dibutuhkan oleh pihak manajemen untuk mengendalikan semua kegiatan bisnsnis dalam oganisasi atau perusahaan pada tahap analisis konsekuensi tiap alternatif tindakan yang digunakan dalam pengambilan keputusan. Keputusan dihasilkan informasi akuntansi merupakan sistem yang diperoleh dari pemrosesan transaksi menjadi data kemudian proses lanjutan menjadi informasi ekonomi organisasi berupa laporan keuangan yang diperlukan user untuk merencanakan, mengendalikan dan mengoperasikan bisnis.

Pengendalian bisnis online sebagai perangsang unit aktivitas bisnis untuk mengurangi resiko dan mencari solusi permasalahan aktibat kesalahan para manajemen dalam mengelolah usaha/bisnis tidak sesuai dengan sasaran yang ditetapkan dalam anggaran, Maka gambar 1. di bawah ini menguraikan sistem informasi akuntansi dalam mengendalikan bisnis on-line.

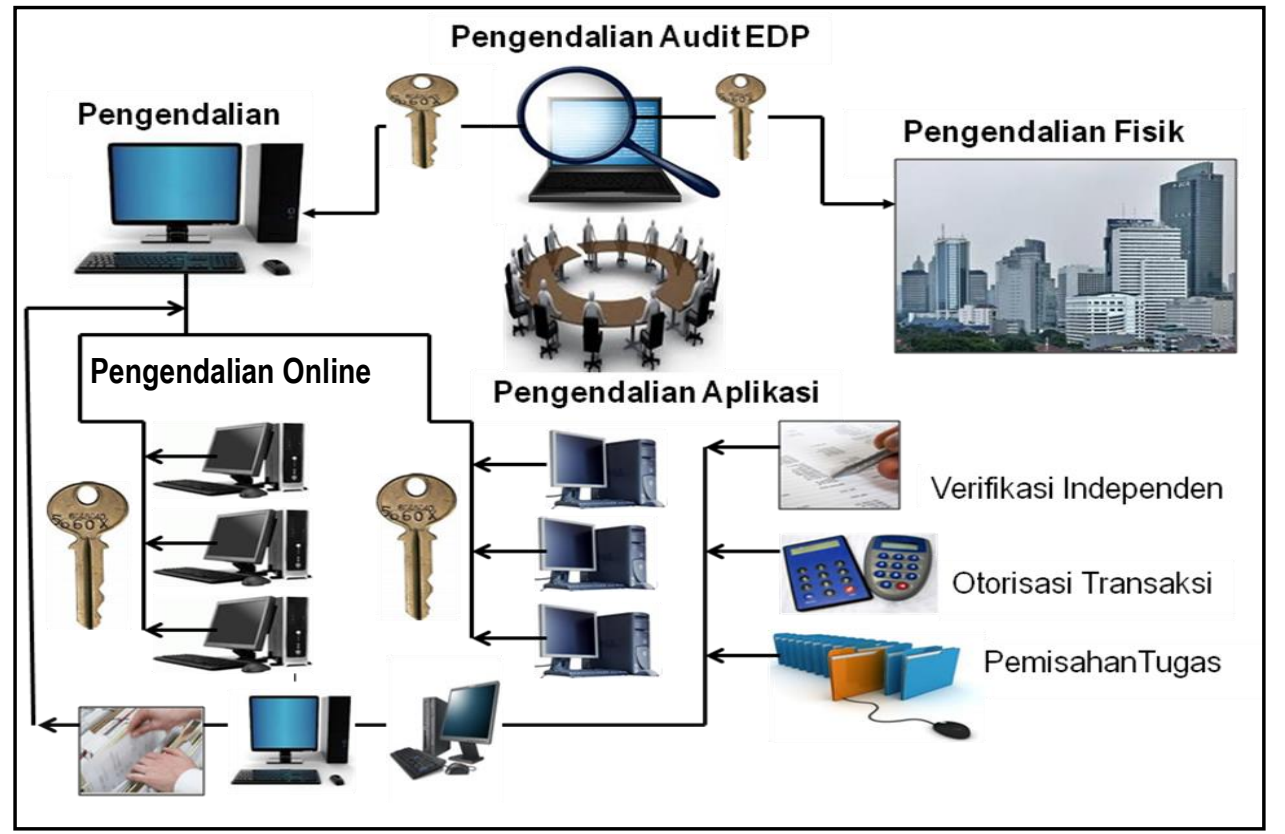

Gambar 1. Sistem Informasi Akuntansi Dalam Mengendalikan Bisnis On-Line

Berdasarkan gambar 1. sistem informasi akuntansi dalam mengendalikan bisnis on-line diatas, maka hal-hal yang diperlukan dalam mengendalikan bisnis online terdiri dari Pengendalian Audit Electronic Data Processing (EDP), Pengendalian Sistem Online dan Pengendalian Aplikasi.

Pengendalian Audit Electronic Data Processing (Audit EDP); pengendalian bisnis online melalui pengendalian fisik yakni audit fisik aplikasi yang digunakan sebab aplikasi/sofware online terhubung dengan para supplier dan pelanggan secara online dalam proses aktivitas bisnis online. Ruang lingkup audit EDP antara lain: Pengembangan system, Pengelolaan layanan teknologi informasi, Operasionalisasi teknologi informasi (server dan infrastruktur), Pemilihan solusi teknologi informasi, Pengelolaan SDM teknologi informasi, Pengelolaan keamanan teknologi informasi, Pengelolaan risiko teknologi informasi dan Pengelolaan kualitas teknologi informasi. Tujuan pengendalian Audit EDP, antara lain : adanya kerugian akibat kehilangan data, 
terjadi kesalahan dalam pengambilan keputusan, adanya risiko kebocoran data, penyalahgunaan computer, kerugian akibat kesalahan proses perhitungan dan tingginya nilai investasi perangkat keras dan perangkat lunak komputer

Pengendalian Sistem Online; terdiri dari (a) Pengendalian masukan dalam sistem on line untuk memberikan keyakinan yang memadai bahwa transaksi di entri ke terminal yang semestinya, di entri dengan cermat, data yang dientri telah diklasifikasikan dengan benar pada nilai transaksi yang sah (valid), data yang tidak sah (invalid) tidak di entri pada saat transaksi, transaksi tidak di entri lebih dari sekali, dan data yang dientri tidak hilang selama transaksi berlangsung. (b) Pengendalian pengolahan pada sistem on line. Pengendalian ini didesain untuk memberikan keyakinan bahwa: hasil perhitungan telah diprogram dengan benar, logika yang digunakan dalam proses pengolahan adalah benar, file yang digunakan dalam proses pengolahan adalah benar, record yang digunakan dalam proses pengolahan adalah benar, operator telah memasukkan data ake komputer consule sebagaimana mestinya, label yang digunakan selama proses pengolahan adalah benar, selama proses pengolahan telah digunakan standar operasi (default) yang semestinya, data yang tidak sah tidak digunakan dalam proses pengolahan, proses pengolahan tidak maenggunakan program dengan versi yang salah, hasil perhitungan yang dilakukan secara otomatis oleh program adalah sesuai dengan kebijakan manajemen organisasi, dan data masukan yang diolah adalah data yang berotorisasi.

Pengendalian keluaran pada sistem on line. Didesain untuk memberikan keyakinan bahwa : (a) keluaran yang diterima organisasi adalah tepat dan lengkap, (b) keluaran yang diterima organisasi telah terklasifikasi dan (c) keluaran didistribusikan kepada pegawai yang telah berotorisasi. Prosedur yang dilaksanakan oleh auditor untuk mengendalikan aplikasi perangkat lunak audit meliputi: (a) Partisipasi dalam perancangan dan pengujian program computer; (b) Pengecekan pengkodean program untuk menjamin bahwa pengkodean tersebut sesuai dengan spesifikasi program rinci; (c) Permintaan kepada staf komputer entitas untuk me-review perintahperintah sistem operasi untuk menjamin bahwa perangkat lunak tersebut akan berjalan dalam instalasi komputer entitas; (d) Pengoperasian perangkat lunak audit tersebut untuk file uji kecil (small test file) sebelum menjalankannya untuk file data utama; (e). Penjaminan bahwa file yang benar yang digunakan-sebagai contoh, dengan cara mengecek ke bukti luar, seperti total kontrol yang diselenggarakan oleh pemakai; (f). Pemerolehan bukti bahwa perangkat lunak audit tersebut berfungsi sebagai mana direncanakan-seperti, review terhadap informasi keluaran dan pengendalian; (g). Penciptaan cara-cara pengamanan yang semestinya untuk menjaga keamanan Untuk menjamin prosedur pengendalian semestinya, kehadiran auditor bukan merupakan keharusan di fasilitas komputer namun, kehadiran auditor di fasilitas komputer dapat memberikan manfaat, seperti ia dapat mengawasi distribusi keluaran dan dapat memastikan koreksi atas kekeliruan dilakukan pada saat yang terdapat kesalahan file masukan yang digunakan dalam menjalankan TABK.

Pengendalian Aplikasi; Pengendalian aplikasi dan pengembangan sistem dan pemeliharaannya, memberikan keyakinan yang wajar bahwa kegiatan berikut ini dilaksanakan secara tepat, yaitu : (1) Pengendalian sistem aplikasi yakni untuk memberikan keyakinan dalam pengujian, penggantian, implementasi dokumentasi dari sistem yang baru atau yang diperbaiki , perubahan terhadap sistem dokumentasi, akses terhadap sistem aplikasi dan pembelian sistem aplikasi dari pihak ketiga. (2) Pengendalian terhadap operasi komputer, yakni pengendalian ini untuk memberikan keyakinan bahwa komputer hanya digunakan petugas yang telah diotorisasi, sistem komputer hanya digunakan untuk maskud yang telah ditentukan, hanya program tertentu 
yang dipakai dan kesalahan-kesalahan suatu proses telah dicari dan dikoreksi, (3) Pengendalian pada sistem software yakni Pengendalian ini didesain untuk memberikan keyakinan bahwa sistem yang dibeli atau dibuat telah dilaksanakan sesuai dengan otorisasi dan dilaksanakan secara efisien. Pengendalian ini meliputi otorisasi, penjamahan, pengujian, penerapan, dan dokumentasi, dan pembatasan orang-orang yang akan melakukan akses ke sistem software, yaitu petugas yang berhak boleh melakukan akses ke komputer, (4) Pengendalian terhadap program dan input data. Pengendalian ini didesain untuk memberikan keyakinan bahawa sebelum data dimasukan harus ada prosedur persetujuan dari petugas tertentu dan akses pada data program hanya terbatas pada petugas tertentu. (5) Pengendalian Proses yakni Pengendalian aplikasi PDE dapat dibagi berdasarkan prosesnya antara lain Pengendalian Input, Pengendalian Proses

\section{Analisis Electronic Commerce dalam Mengendalikan Bisnis On-Line}

Pengendalain transaksi online internet merupakan salah satu aspek terpenting dalam sistem infomasi akuntansi, khususnya transaksi pembayaran yang dilkaukan secara online dengan e-commerce, e-payment, e-fund transfer, internet banking, mobile banking. Pengendalaian untuk akses atau modifikasi data secara ilegal, phishing, zombies, denial of service, gangguan virus, worm, trojan pada sistem operasi komputer atau data, pencurian data, pemalsuan web atau situs pembeli. Berikut ini gambar 2. Dibawah ini menguraikan electronic commerce dalam mengendalikan bisnis on-line.

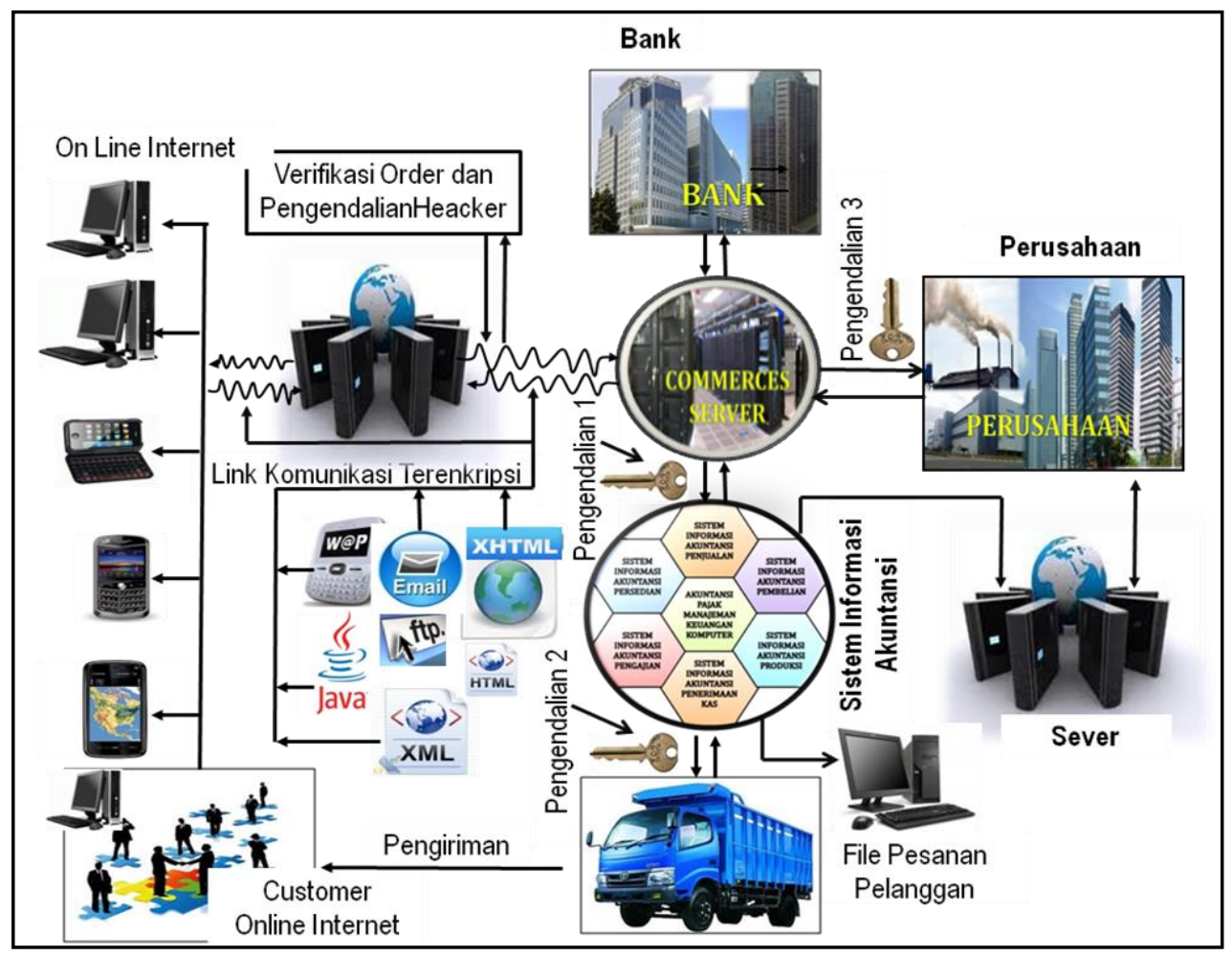

Gambar 2. Electronic Commerce Mengendalikan Bisnis On-Line 
Berdasarkan Gambar 2. Penerapan electronic commerce mampu mengendalikan Bisnis on-line adalah sebagai berikut :

1) Online/internet : Seluruh transaksi pembelian dan pembayaran yang dilkukan secara online internet terhubung ke komputer penjual

2) Verivikasi order dan pengendalian Heacker : pengendalian yang dapat dilakukan oleh penjual dan penerima pembayaran via online melalui verifikasi dokumen-dokumen dalam internet, seperti pemeriksaan data customer, alamat, jumlah dan nilai pesanan

3) Bank: Bagian pengendalian dalam system informasi akuntansi melalakukan klarifikasi dengan saldo rekening Koran, melihat jumlah uang yang diterima melalui internet banking dan memcocokkan data customer dengan catatan dalam rekening Koran perusahaan melalui internet banking.

4) Sistem informasi akuantansi, dalam gambar 3. di tunjjukan lokasi dan wilayah pengendalian 1 dan pengendalian 2 sebelum data diterima dan setelah data diterima untuk diperoses lebih lanjut dalam perusahaan

Pengendalian sistem informasi akuntansi melalui electronic commerce dalam mengendalikan Bisnis on-line, dimana perusahaan menggunakan e-commerce untuk menawarkan produk, pembuatan invoice dan penerimaan pembayaran secara online. Perusahaan dapat mengendalikan berdasarkan tipe e-Commerce seperti B2B dan B2C. Pengendaliaan ini dapat kita perhatikan pada gambar 3 . di bawah ini.

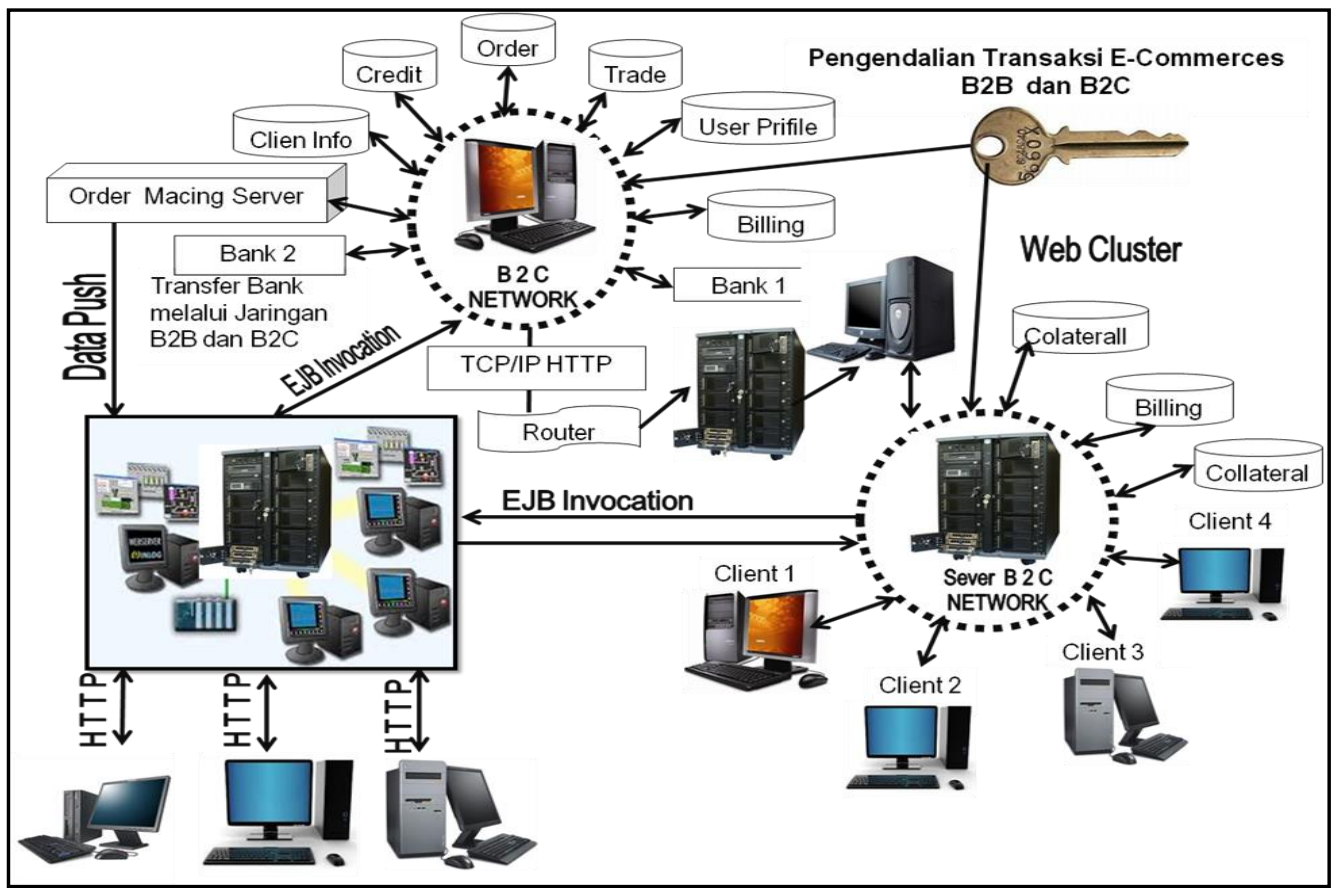

Gambar 3. Sistem Informasi Akuntansi dan Electronic Commerce Dalam Mengendalikan Bisnis On-Line

Sistem informasi akuntansi dan audit electronic data processing melalui electronic commerce sangat menentukan dalam mengendalikan transaksi pembayaran on-line sesuai gambar 3. diatas, menunjukkan pengendalian melalui B2B dan B2C dari beberapa jenis transaksi dengan pihak-pihak yang terhubung secara online antara lain : (a) Busines to Busines (B2B), 
pengendlian sistem komunikasi bisnis online antar pelaku bisnis, berupa transaksi InterOrganizational System (IOS), misalnya transaksi extranet dan electronic funds transfer. (b) Bussines to Cunsumer (B2C), pengendalian transaksi ritel dengan pembeli individual. Selain itu B2C juga dapat berarti mekanisme toko online (electronic shoping mall) yaitu transaksi antara emerchant dengan e-customer.

\section{REKOMENDASI DAN KEBIJAKAN}

\section{Rekomendasi}

Berdasarkan pembahasan pada bab-bab sebelumnya dan dengan berpedoman pada permasalahan dalam penelitian ini, maka dari penelitian ini dapat diambil beberapa kesimpulan sebagai berikut

1. Peranan Sistem informasi akuntansi terhadap pengendalian bisnis Online terdiri dari tiga kelompok pengendalaian, antara lain: (a) Pengendalian Audit Electronic Data Processing (Audit EDP); pengendalian bisnis online melalui pengendalian fisik yakni audit fisik aplikasi yang digunakan sebab aplikasi/sofware online terhubung dengan para supplier dan pelanggan secara online dalam proses aktivitas bisnis online untuk mengendalikan kehilangan data, terjadi kesalahan dalam pengambilan keputusan, adanya risiko kebocoran data, penyalahgunaan computer, kerugian akibat kesalahan proses perhitungan dan tingginya nilai investasi perangkat keras dan perangkat lunak komputer. (b) Pengendalian Sistem Online; yakni Pengendalian masukan dalam sistem on line untuk memberikan keyakinan yang memadai bahwa transaksi di entri ke terminal yang semestinya, di entri dengan cermat, data yang dientri telah diklasifikasikan dengan benar pada nilai transaksi yang sah (valid), data yang tidak sah (invalid) tidak di entri pada saat transaksi, transaksi tidak di entri lebih dari sekali, dan data yang dientri tidak hilang selama transaksi berlangsung. (c) Pengendalian Aplikasi; pengendalian memberikan keyakinan yang wajar bahwa kegiatan bisnis dilaksanakan secara tepat dan efisien dalam sistem aplikasi, operasi komputer, telah diotorisasi, pembatasan orang-orang yang akan melakukan akses ke sistem software.

2. Peranan Sistem informasi akuntansi dalam Electronic Commerce terhadap Pengendalian Bisnis On-Line, bahwa Pengendalain bisnis online menggunakan jaringan online internet untuk transaksi sebagai salah satu aspek terpenting dalam sistem infomasi akuntansi, khususnya transaksi pembayaran yang dilkaukan secara online dengan e-commerce, epayment, e-fund transfer, internet banking, mobile banking. Pengendalaian untuk akses atau modifikasi data secara ilegal, phishing, zombies, denial of service, gangguan virus, worm, trojan pada sistem operasi komputer atau data, pencurian data, pemalsuan web atau situs pembeli.

\section{Kebijakan}

Pengendalian bisnis online tujuannya untuk mengendalikan aktivitas bisnis khususnya pembayaran melalui online internet dalam e-commerce dengan dapat dikendalikan melalui penerapan sistem informasi akuntansi dan audit EDP dengan jaringan internet meliputi pengendalian aspek autentikasi, autorisasi, auditing, accounting, konfidensialitas dan integritas, ketersediaan dan nonrepudiasi yang dapat terjadi pada e-commerce termasuk Keamanan jaringan pengendalian akses. 


\section{DAFTAR PUSTAKA}

Bodnar, George H. and William S. Hopwood (2008). Sistem Informasi Akuntansi. Edisi Indonesia. Terjemahan. Jakarta : Salemba Empat.

Budilaksono Agung (2011), Teori EDP dan Audit EDP Audit EDP, Kementerian Keuangan Republik IndonesiaBadan Pendidikan Dan Pelatihan Keuangan Pusdiklat Bea Dan Cukai, STAN - Jakarta.

Departemen Keuangan Republik Indonesia (2007), Pengantar Informasi Audit Sistem, Sekolah Tinggi Akuntansi Negara, Badan Pendidikan dan Pelatihan Keuangan (BPPK). Bintaro Jaya Tangerang.

Hall, James A dan Singleton, Tommie (2007), Audit dan Assurance Teknologi Informasi, Salemba Empat

Hall, James A (2009), Accounting Information System (Sistem Informasi Akuntansi), Jilid 1. Salemba Empat Edisi 4, Bahasa Indonesia

Irwan, Prasetya (2006), Penelitian Kualitatif dan Kuantitatif untuk IImu-ilmu Sosial, Departemen IImu Administrasi Fakultas IImu Sosial dan IImu Politik Universitas Indonesia, Depok.

Manik, Tumpal (2016), Sistem Informasi Akuntansi (Accounting Information Systems) Secara Teori dan Studi Kasus Kolaborasi Akuntansi dengan Teknologi Informasi. Umrah Press Tanjungpinang

Marcella Elwina S (2011), Aspek Hukum Transaksi (Perdagangan) Melalui Media Elektronik (ECommerce) Di Era Global: Suatu Kajian Perlindungan Hukum Terhadap Konsumen

Noviari Naniek (2008), Pengaruh Kemajuan Teknologi Informasi Terhadap Perkembangan Akuntansi. Jurusan Akuntansi Fakultas Ekonomi Universitas Udayana. Bali

Nurharyanto (2009). Dasar - Dasar Audit, Badan Pengawasan Keuangan Dan Pembangunan, (2009). Edisi ke-6. BPK Jakarta.

O'Brien James A, Marakas George Marakas (2010), Management Information Systems, 9th ed. McGraw Hill.

Rommey Marshall B, 2005, Sistem Informasi Akuntansi Edisi 9 Terjemahan, Penerbit Salemba Empat Jakarta.

Singleton Tommie (2007), Information Technology Auditing and Assurance diterjemakan Audit Assurance Teknologi Informasi. Salemba Empat Jakarta

Sugiono (2011), Metode Penelitian Kiuantitatif, Kualitatif dan Kombinasi (Mixed Methods). Alfabeta. Bandung 